\title{
Stapled Circumcostal Mesh Repair for Chest Wall Reconstruction
}

\author{
Ming-Fang Yin ${ }^{1}$, RN Shun-Mao Yang ${ }^{1}$ and Pei-Ming Huang ${ }^{2}$ \\ ${ }^{1}$ Division of Thoracic Surgery, Department of Surgery, National Taiwan University Hospital, Taiwan \\ ${ }^{2}$ National Taiwan University College of Medicine, Taiwan
}

Submission: February 22, 2017; Published: March 06, 2017

*Corresponding author: Pei-Ming Huang, Department of Surgery, National Taiwan University Hospital and National Taiwan, University College of Medicine, Taipei, Taiwan 7, Chung-Shan South Road, Taipei 10002, Taiwan, Tel: +886-2- 23123456, ext. 63509; Fax: +886-2- 23415736;

Email: e370089@gmail.com

\begin{abstract}
Surgical resection is indicated for most primary and metastatic chest wall malignancies. Synthetic mesh repair after chest wall resection had been widely adopted, and assortedmethodshave been proposed with various materials and surgical techniques. In contrast to conventional suture fixation of the mesh covering the defect area, we present a new reconstruction method involving double-layer mesh placed around the ribs on either side of the chest wall defect and secured using a linear stapler. This methodcan provide firm tissue closure and has the advantages of preventing herniation of the lung and providing mechanical protection againstexteriorimpacts.
\end{abstract}

Keywords: Chest Wall Reconstruction; Mesh Repair

\section{Introduction}

Curative surgical resection for selected primary chest wall neoplasms, and chest wall resection for metastatic neoplastic lesions with no other distant metastases, have longterm survival benefits [1]. Various synthetic mesh materials combined with metal plates and bone cement have been widely used in chest wall reconstruction [2,3]. However, reconstruction remains challenging, and novel techniques designed for different cases have been repeatedly reported. Here, we describe a novel technique using a double-layer mesh and inner surgical membrane placed around the ribs on either side of the chest wall defect and secured using a linear stapler after resection of a metastatic rib tumor.

\section{Case Presentation}

A 50-year-old man received right radical nephrectomy for renal cell carcinoma, and follow-up image studies of chest computed tomography (CT) and positron emission tomography revealed a progressive metastatic bone lesion over the left 5 th rib,which was confirmed with CT-guided biopsy (Figure 1). After induction of general anesthesia, the patient was placed in the semi-decubitus position. A transverse incision was made over the lesion site, and excision was performed with adequate margins (medial to parasternal area and lateral to mid-axillary area) and a $5 \times 11 \mathrm{~cm}$ chest wall defect. Dissection was performedfrom the upper margin of the 4 th rib to the lower margin of the 6 th rib.
Care should be taking not to injure the nerve and vessels during separating bony part of the ribs from the neighboring intercostal muscle flap.

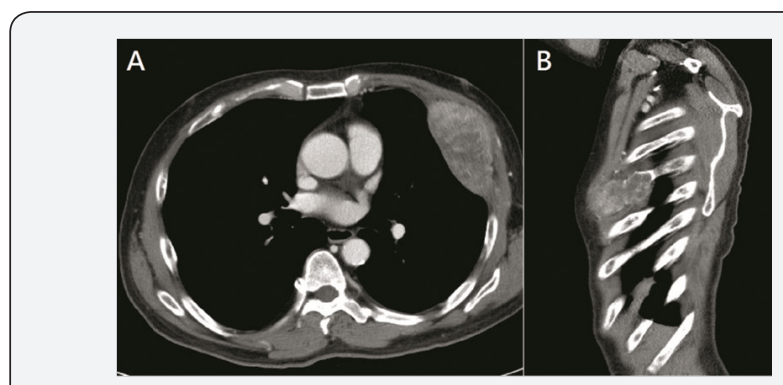

Figure 1: Computed tomography images of the chest show a large $11 \times 6 \times 5 \mathrm{~cm}$ elliptical shaped bone tumor over the left 5 th rib. (A)Axial view. (B)Sagittal view.

A folded hernia mesh (BARD ${ }^{\text {TM }}$ Mesh, Davol Inc.) with a nonabsorbable surgical membrane(Gore-Tex ${ }^{\circledR}$ Surgical Membrane, W. L. Gore \& Associates, Inc.) attached to the inner side was placed around the upper margin of the 4 th rib and lower margin of the 6th rib (Figure 1). Then, a linear stapler was used to join the opposing sides of the mesh (Figure 2), and the remaining healthy soft tissue and skin were closed routinely. The pathology report showed metastatic renal cell carcinoma, and the soft tissue and bony margin were uninvolved but he also received further adjuvant radiotherapy and target regiment of sunitinib. 
At six months postoperatively, the patient remained well and had excellent chest wall integrity. No intercostal neuralgia was noted, and the cosmetic result was acceptable.

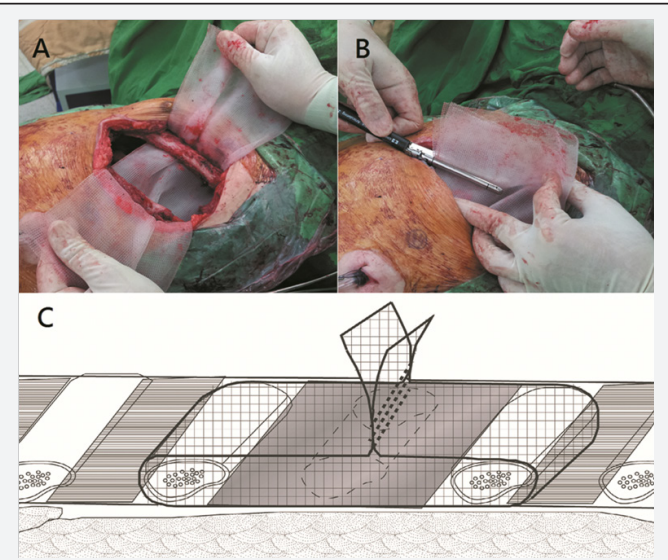

Figure 2: (A) The folded hernia mesh (BARD ${ }^{\mathrm{TM}}$ Mesh, Davol Inc.) with a non-absorbable surgical membrane (Gore-Tex® Surgical Membrane, W. L. Gore \& Associates, Inc.) attached to the inner side is placed around the upper margin of the 4th rib and the lower margin of the 6th rib. (B) A linear stapler is applied along the conjoining line of both sides of the mesh. (C) The double-layer mesh secured around the ribs provides adequate strength for protection from outer mechanical forces and allows radiographic follow-up of the underlying problem.

\section{Discussion}

Reconstruction after chest wall resection is highly individualized and depends on the defect size, remaining structures including bony parts and soft tissue, and necessity of further radiotherapy. Various strategies including primary tissue closure, synthetic mesh repair, and complex artificial bone reconstruction have been proposed to restore the protective and physiological functions of the chest wall as well as address cosmetic concerns.1 Resection of bony parts is usually inevitable during chest wall surgery; however, the indications for bony repair remain controversial. In general, all full-thickness bony defects with potential for paradoxical movement should be reconstructed, and the choice of reconstruction method depends on the size and location of the defect.

Small defects $(<5 \mathrm{~cm})$ and those located posteriorly under the scapula are usually closed with only soft tissue, while stabilization of larger defects $(>5 \mathrm{~cm})$ is indicated [4]. Location of the chest wall defect influences the need for skeletal stabilization, particularly for lateral defects, which lack sternal or spinal stability [4]. Although previous study states that most patients can tolerate sternectomy or multiple rib resection at the cartilage level without flail chest or respiratory insufficiency [4] many case reports have shown lung herniation in patients in whom the defect size was considered small and not in need of repair. Further, small chest wall defects increase the risk of incarceration and make reduction more difficult [5]. Currently, mesh repair combined with use of metal ribs is widely used; however, metal ribs may compromise future radiotherapy and should only be used if there is great confidence regarding the margins [5].

In our case, a single rib was resected with a lateral chest wall defect larger than $5 \mathrm{~cm}$; thus, bony repair might have been indicated according to the defect size and location. Meanwhile, the remaining soft tissue was sufficient for wound closure and flap repair was not required [6]. The hernia mesh was the main part of our reconstruction, which provided the protecting strength. Non-absorbable Gore-Tex® surgical membrane which attached to the inner side was used to prevent lung adhesion to mesh. Our method provided adequate strengthand cushioning for protection from outer mechanical forces, and was considered superior to reconstruction using merely rigid materials such as metal ribs and titanium mesh except for the apical lesions [7]. In addition to facilitating use of primary soft tissue closure, this method helped prevent lung herniation and no paradoxical movement.

Regarding long-term clinical requirements, chest reconstruction using only mesh has superior inertness to allow ingrowth of fibrous tissue with decreased likelihood of infection and radiolucency to allow radiographic follow-up of the underlying problem [8]. Regarding chest wall defects with more than a single rib resected, this technique can theoretically be applied provided the remaining ribs on either side of the defect can be wrapped by the mesh. We believe that this new method may be useful in supplemental reinforcement for primary soft tissue closure or autologous flap repair in chest wall reconstruction because it provides additional protection strength and helps prevent lung herniation.

\section{Acknowledgement}

This case report had no possible conflict of interest and no sources of funding exist.

\section{References}

1. Rocco G, Mori S, Fazioli F, La Rocca A, Martucci N, et al. (2012) The use of biomaterials for chest wall reconstruction 30 years after radical surgery and radiation. Ann Thorac Surg 94(4): 109-110.

2. Miller DL, Force SD, Pickens A, Fernandez FG, Luu T, et al. (2013) Chest wall reconstruction using biomaterials. Ann Thorac Surg 95(3): 10501056.

3. Barua A, Catton JA, Socci L, Raurell A, Malik M, et al. (2012) Initial experience with the use of biological implants for soft tissue and chest wall reconstruction in thoracic surgery. Ann Thorac Surg 94(5): 17011705.

4. Chang SH, Tung KY, Hsiao HT, Chen CH, Liu HK (2011) Combined free vascularized iliac osteocutaneous flap and pedicled pectoralis major myocutaneous flap for reconstruction of anterior chest wall fullthickness defect. Ann Thorac Surg 91(2): 586-588.

5. Coonar AS, Qureshi N, Smith I, Wells FC, Reisberg E, et al. (2009) A novel titanium rib bridge system for chest wall reconstruction. Ann Thorac Surg 87(5): 46-48.

6. Chang RR, Mehrara BJ, Hu QY, Disa JJ, Cordeiro PG (2004) Reconstruction of complex oncologic chest wall defects: a 10-year experience. Ann Plast Surg 52(5): 471-479. 
7. Dast S, Berna P, Qassemyar Q, Sinna R (2012) A new option for autologous anterior chest wall reconstruction: the composite thoracodorsal artery perforator flap. Ann Thorac Surg 93(3): 67-69.
8. Bosc R, Lepage C, Hamou C, Matar N, Benjoar MD, et al. (2011) Management of chest wall reconstruction after resection for cancer: a retrospective study of 22 consecutive patients. Ann Plast Surg 67(3): 263-268.

\section{Your next submission with Juniper Publishers will reach you the below assets}

- Quality Editorial service

- Swift Peer Review

- Reprints availability

- E-prints Service

- Manuscript Podcast for convenient understanding

- Global attainment for your research

- Manuscript accessibility in different formats

( Pdf, E-pub, Full Text, Audio)

- Unceasing customer service

Track the below URL for one-step submission https://juniperpublishers.com/online-submission.php 